\title{
Fetal Hemoglobin Expression in Transplant Recipients of Placental Blood Hematopoietic Progenitor Cells
}

\author{
GEORGE R. HONIG, LOYDA N. VIDA, GEORGE E. HOGANSON, JR., JOHN C. SCHULTZ, AND \\ NASROLLAH T. SHAHIDI \\ Department of Pediatrics, University of Illinois, Chicago, Illinois 60612 [G.R.H., L.N.V., G.E.H.] and \\ Department of Pediatrics, University of Wisconsin, Madison, Wisconsin 53792 [J.C.S., N.T.S.]
}

\begin{abstract}
Patients who achieved bone marrow engraftment of cord blood-derived progenitor cells provided an opportunity to examine the expression of fetal $\mathrm{Hb}$ by nconatal hematopoietic progenitors in a postneonatal host. Cord blood cells from histocompatible siblings were successfully transplanted in two children with the Fanconi ancmia syndrome. One of the transplant donors had hetcrocellular hereditary persistence of fetal $\mathrm{Hb}$, apparently due to $\gamma$-globin gene triplication; the other donor was hematologically normal. The ${ }^{\mathrm{C}} \gamma /{ }^{\wedge} \gamma$ ratio of the patient who received his transplant from the donor with hereditary persistence of fetal $\mathrm{Hb}$ was markedly elevated, similar to that of the transplant donor's cord blood, and this ratio remained elevated in subsequent months. In the other child, the ${ }^{\mathrm{G}} \gamma /{ }^{\wedge} \gamma$ ratio immediately after her transplant was typical of the normal newborn, and over the next
\end{abstract}

ABSTRACT
Blood obtained from the placenta and umbilical cord of newborn infants has becn shown to be a rich source of hematopoictic progenitor cells (1). Cord blood cclls offer a number of important advantages compared with bone marrow preparations for bone marrow reconstitution (2), and there has been a considerable increase in recent years in the use of cord blood cells as an alternative to bone marrow transplantation (3). Patients who are successfully transplanted with such progenitor cells achieve engraftment with hematopoietic precursors that normally have a pattern of gene expression corresponding to the fctal/neonatal stage of development. Accordingly, these patients provide an opportunity to examine the possible role of postneonatal cnvironmental factors in the developmental expression of these genes. The $\mathrm{Hb}$ system is a particularly suitable model for approaching this question.

In the fetus and newborn, most of the $\mathrm{Hb}$ in the red cells consists of $\mathrm{Hb} \mathrm{F}$, which is composed of $\alpha$ - and $\gamma$-globin subunits. By 6 mo of agc, nearly all of the $\mathrm{Hb} F$ is replaced by the adult form, $\mathrm{Hb} \mathrm{A}$, which is made up of $\alpha$ and $\beta$ subunits. The factors that control this $\gamma$ to $\beta$ switch have been a subject

Received July 8, 1994; accepted November 11, 1994.

Correspondence: George R. Honig, M.D., Ph.D., University of Illinois College of Medicine, Department of Pediatrics (M/C 856), 840 South Wood St., Chicago, IL 60612. several months it reverted to the adult pattern. Globin synthesis studies performed shortly after engraftment demonstrated ratios of fetal $\mathrm{Hb} / \mathrm{adult} \mathrm{Hb}$ synthesis in both patients that were typical of those of normal newborns. Over the next several months, both patients converted to the adult pattern. Fetal $\mathrm{Hb}$ to adult $\mathrm{Hb}$ switching in these patients seemed to follow a temporal sequence intrinsic to the transplanted neonatal progenitor cells, without discernible influence of postneonatal environmental factors. The program for $\mathrm{Hb}$ switching seems to be an inherent feature of neonatal hematopoietic progenitor cells. (Pediatr Res 37: 432436,1995 )

Hb F, fetal Hb

\section{Abbreviations}

of intense study in recent ycars, in part because of the therapeutic advantages that might be realized if this process could be controlled or reversed in individuals with $\beta$-globin gene abnormalities.

The patients we describe in this report achieved bone marrow reconstitution with hematopoietic progenitor cells obtained at birth from their histocompatible siblings. In each case, the cell donors expressed primarily $\mathrm{Hb} F$ at the time the progenitor cells were harvested. The recipients were both well beyond the developmental stage when the $\gamma$ to $\beta$ switch is normally completed.

\section{METHODS}

Hematologic and $\mathrm{Hb}$ measurements. Procedures for erythrocyte and $\mathrm{Hb}$ quantification (4), the preparation of $\mathrm{Hb}$ solutions for analysis, $\mathrm{Hb}$ electrophoresis, and measurements of $\mathrm{Hb}$ $\mathrm{F}$ and $\mathrm{Hb} \mathrm{A}_{2}$ (5) were as described previously.

$\boldsymbol{H} \boldsymbol{b}$ studies. The procedures for globin chain fractionation and quantitative estimation used HPLC with a $\mathrm{C}_{4}$ column (Vydac, The Separations Group, Hesperia, CA) with acetonitrile-water-trifluoroacetic acid gradient elution (6). For globin synthesis studies, washed red cells were incubated for $2 \mathrm{~h}$ at $37^{\circ} \mathrm{C}$ in medium containing L-leucine- ${ }^{3} \mathrm{H}$, as previously de- 
scribed (7). Column chromatography of the labeled globins (8) followed the methods of Clegg et al. (9).

DNA analyses. DNA was prepared from blood leukocytes as described by Poncz et al. (10). Digests with XmnI and/or PstI were analyzed by the Southern blotting technique (11) using a $\gamma$ IVS-II probe.

Patient 1 . This child, currently $8 \mathrm{y}$ of age, was noted at birth to have anomalies of her upper extremities. She was later found to have stenotic ear canals, horseshoe kidneys, café au lait spots, and growth retardation. At 13 mo of age, a chromosomal analysis of her blood mononuclear cells, after incubation with mitomycin $\mathrm{C}$, revealed abnormally increased chromosomal breakages, confirming the diagnosis of Fanconi anemia. At 2.5 $\mathrm{y}$, her $\mathrm{Hb}$ concentration was $12 \mathrm{~g} / \mathrm{dL}$, and her platelet count $106000 / \mu \mathrm{L}$. Her blood count values declined steadily thereafter, and at 4 y of age her $\mathrm{Hb}$ concentration was $7 \mathrm{~g} / \mathrm{dL}$ and her platelet count $24000 / \mu \mathrm{L}$. Six months later, she was conditioned with cyclophosphamide and thoracoabdominal radiation (12) and received a cord blood transplant from her HLAidentical sister. The total volume of the cord blood was 285 $\mathrm{mL}$, with a total nucleated cell count of $9.6 \times 10^{8}(0.75 \times$ $10^{8} / \mathrm{kg}$ ). The patient achieved successful engraftment; on d 19 posttransplant, her $\mathrm{Hb}$ concentration was $10.8 \mathrm{~g} / \mathrm{dL}$, her neutrophil count $1150 / \mu \mathrm{L}$, and her platelet count $109000 / \mu \mathrm{L}$. This child (and patient 2 described below) received cyclosporine as their only posttransplant immunosuppressive treatment.

Patient 2. This boy, who presented with thrombocytopenia at age $4.5 \mathrm{y}$, was found to have a variety of anomalies including atresia of the auditory canals, thumb abnormalies, café au lait spots, and fused kidneys. The diagnosis of Fanconi anemia was confirmed by chromosomal analysis after incubation of his cells with diepoxybutanc. Before transplantation, at the age of $6.5 \mathrm{y}$, his $\mathrm{Hb}$ concentration was $7.2 \mathrm{~g} / \mathrm{dL}$, his leukocyte count $1600 / \mu \mathrm{L}$ with an absolute neutrophil count of 1000 granulocytes $/ \mu \mathrm{L}$, and his platelet count $14000 / \mu \mathrm{L}$. He received a total of $75 \mathrm{~mL}$ of cord blood, containing $5.4 \times 10^{8}$ nucleated cells. His preparative regimen was similar to that of patient 1 , with minor modification (13). His posttransplant course was uneventful. The first indications of engraftment were evident by d 14. His last red cell transfusion was given on d 37 posttransplant, and thereafter his $\mathrm{Hb}$ concentration remained $>8 \mathrm{~g} / \mathrm{dL}$. Thirty-six months after his transplant, his blood count was totally normal.

\section{RESULTS}

Patient 1. The parents of this child and the sibling who was her transplant donor all exhibited normal hematologic findings. At $14 \mathrm{wk}$ after her transplant, at a point when the graft was well established, her $\mathrm{Hb} \mathrm{F}$ level was $22.2 \%$ with a ${ }^{\mathrm{G}} \gamma /{ }^{\mathrm{A}} \gamma$ ratio of 1.95; a globin synthesis study demonstrated a $\gamma / \beta$ synthesis ratio of 0.22 . These findings correspond to those seen in normal infants approximately midway through the $\gamma$ to $\beta$ switch.

As controls for this and other globin synthesis studies in these patients, we performed the same determination in three patients shortly following engraftment after allogeneic bone marrow transplants. Their mean $\gamma / \beta$ synthesis ratio was $0.13 \pm 0.03$.
When the patient was restudied 5 mo later, her $\mathrm{Hb} \mathrm{F}$ level was $4 \%$, and her ${ }^{\mathrm{G}} \gamma /{ }^{\wedge} \gamma$ ratio was 0.58 , compatible with a normal early postswitch pattern.

Patient 2. The parents and the transplant donor of this patient also exhibited normal hematologic findings. Analysis of their fetal $\mathrm{Hb}$, however, demonstrated abnormalities in the father and in the sibling whose cord blood served as a source of progenitor cells (Table 1). Both of them had slightly elevated levels of $\mathrm{Hb} \mathrm{F}$, accompanied by substantially increased ${ }^{\mathrm{G}} \gamma /{ }^{\wedge} \gamma$ ratios. The slide-elution test for $\mathrm{Hb} \mathrm{F}$-containing cells (14) showed both of them to have 3 to $6 \%$ strongly positively staining cells, with a clearly heterogeneous distribution.

When the patient was studied approximately 3 mo after transplantation, his erythrocytes contained $18.1 \% \mathrm{Hb} F$ with a ${ }^{\mathrm{G}} \gamma /{ }^{\mathrm{A}} \gamma$ ratio of 5.8. A globin synthesis study at that time (Fig. 1) demonstrated nearly equal rates of synthesis of the $\gamma$ and $\beta$ chains $(\gamma / \beta$ synthesis ratio 0.97$)$, a pattern similar to what we have previously observed in newborns (8).

One month later, the $\mathrm{Hb} \mathrm{F}$ level in his blood increased to $31.5 \%$, but a globin synthesis study at that time showed a significant $\gamma$ to $\beta$ transition, with a $\gamma / \beta$ synthesis ratio of 0.33 . Subsequent levels of $\mathrm{Hb} \mathrm{F}$ in the patient gradually declined (Fig. 2), but even after 1 y they remained significantly elevated. At approximately 16 mo after his transplant, at which time his $\mathrm{Hb} \mathrm{F}$ level was $6.6 \%$, a slide-elution test of his erythrocytes demonstrated that $4.4 \%$ of the cells had a strongly positive staining reaction for $\mathrm{Hb} \mathrm{F}$.

DNA was prepared from blood leukocytes from the patient, his father, and the brother who was his transplant donor. DNA was also prepared from cultured skin fibroblasts from the patient. Digests were made with $X m n I$ and with $X m n \mathbf{I}$ and $P s t \mathrm{I}$.

The DNA fragments from each of these individuals, identified using the $\gamma$ IVS-II probe, were indistinguishable from each other but differed from normal controls. The study shown in Figure 3 used DNA from the patient's fibroblasts. The 7-kb and 8 - $\mathrm{kb}$ fragments in the $\mathrm{XmnI}$ digest reflect a polymorphic site $5^{\prime}$ to the normal ${ }^{\mathrm{G}} \gamma_{-}{ }^{\mathrm{A}} \gamma$ segment (15). The XmnI site $5^{\prime}$ to the ${ }^{\mathrm{G}} \gamma$-globin gene also can account for the additional $4.9-\mathrm{kb}$ fragment in the patient's DNA, suggesting that he and the other affected family members have ${ }^{\mathrm{G}} \gamma^{\mathrm{G}} \gamma^{\mathrm{A}} \gamma$ triplication arrangement. The presence of the additional $4.1-\mathrm{kb}$ and $0.8-\mathrm{kb}$ fragments in the XmnI + PstI digests (Fig. 3) further supports this possibility (15).

\section{DISCUSSION}

Findings from a variety of clinical observations have contributed to the characterization of the normal $\mathrm{Hb}$ switching

Table 1. Hb F measurements from the parents of patient 2 and from the patient's brother, who was his cord blood transplant donor

\begin{tabular}{|c|c|c|c|}
\hline & $\% \mathrm{Hb} \mathrm{F}$ & ${ }^{\mathrm{G}} \gamma /^{\mathrm{A}} \gamma$ ratio & $\begin{array}{l}\text { Hb F slide } \\
\text { elution test }\end{array}$ \\
\hline Father & 1.1 & 9.1 & Positive \\
\hline Mother & 0.3 & $<1.0$ & Negative \\
\hline Donor (cord blood) & 75.6 & 6.2 & \\
\hline Donor $(2-22-91)$ & 4.8 & $>10$ & \\
\hline Donor $(8-9-91)$ & 2.6 & $>10$ & Positive \\
\hline
\end{tabular}




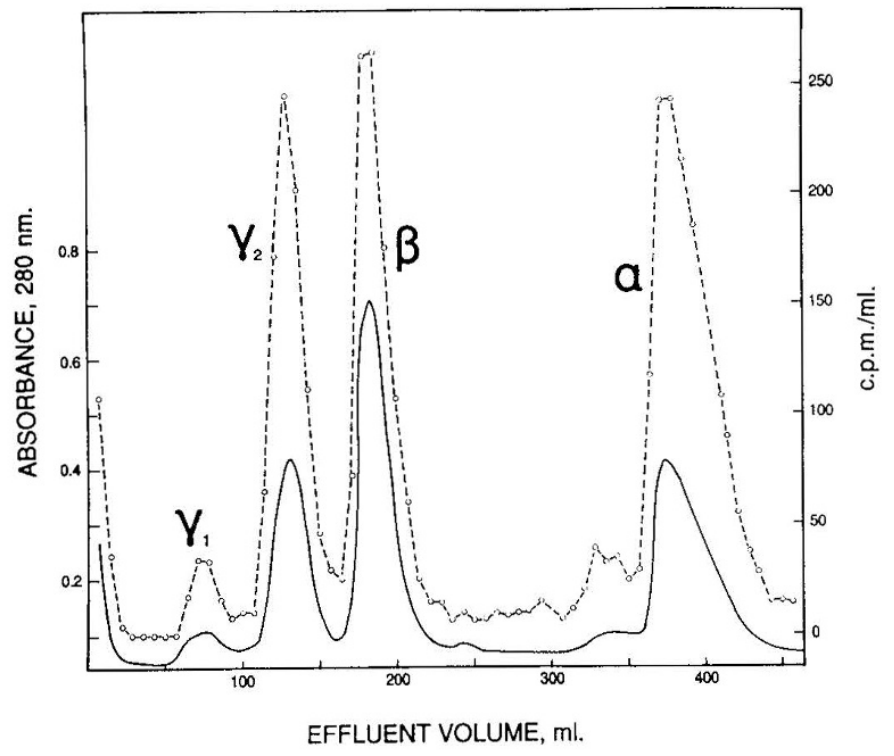

Figure 1. Globin synthesis by blood reticulocytes from patient 2 at approximately 3 mo after his transplant. —— globin protein; $\mathrm{O}_{-----O}$, incorporated L-leucine- ${ }^{3} \mathrm{H}$.

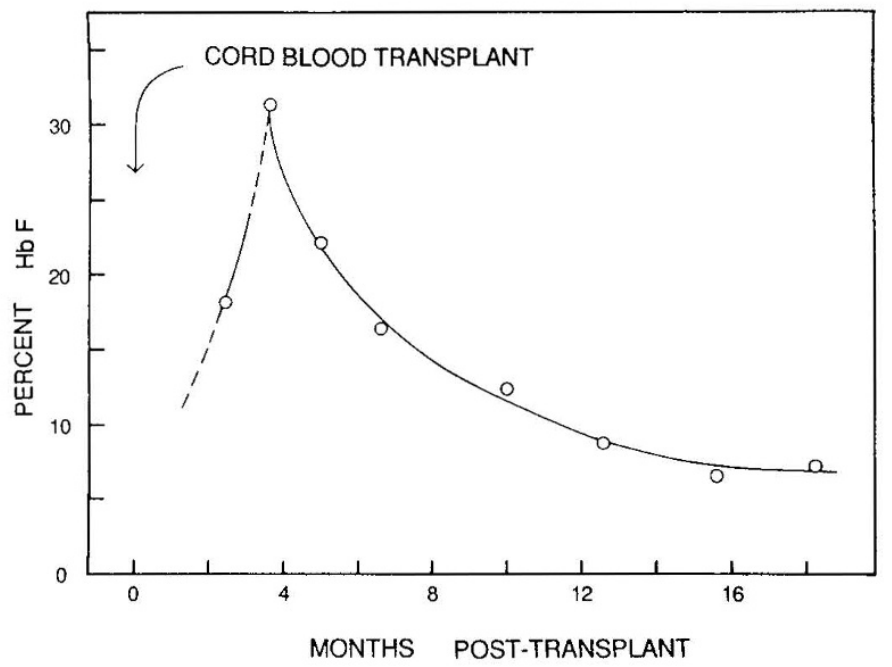

Figure 2. Levels of $\mathrm{Hb} \mathrm{F}$ in patient 2 after his cord blood transplant. At the time he was transplanted (shown by the arrow), he had received extensive transfusions, and therefore he had very little $\mathrm{Hb} F$ in his circulating red cells.

process and also to gaining greater understanding of the role of postneonatal factors in the developmental expression of the $\mathrm{Hb}$ system. In accordance with a widely accepted hypothesis that relates $\mathrm{Hb} \mathrm{F}$ expression to the stage of erythropoietic maturation $(16,17)$, erythroid cells in earlier stages of maturation have been shown to produce proportionally larger amounts of fetal $\mathrm{Hb}(18)$. This change is central to explaining the elevated levels of $\mathrm{Hb} \mathrm{F}$ associated with "stress erythropoiesis," and it also has been postulated as a potential mechanism for the control of Hb switching.

In studies of $\mathrm{Hb}$ expression in baboons, in which erythropoiesis was stimulated by phlebotomy, acute hemolysis, or hypobaric hypoxia $(19,20)$, high levels of $\mathrm{Hb} \mathrm{F}$ could be achieved and sustaincd for extended periods of time by continuation of the erythropoietic stimuli. In human newborn infants with hemolytic disease, in whom erythropoietic regen-

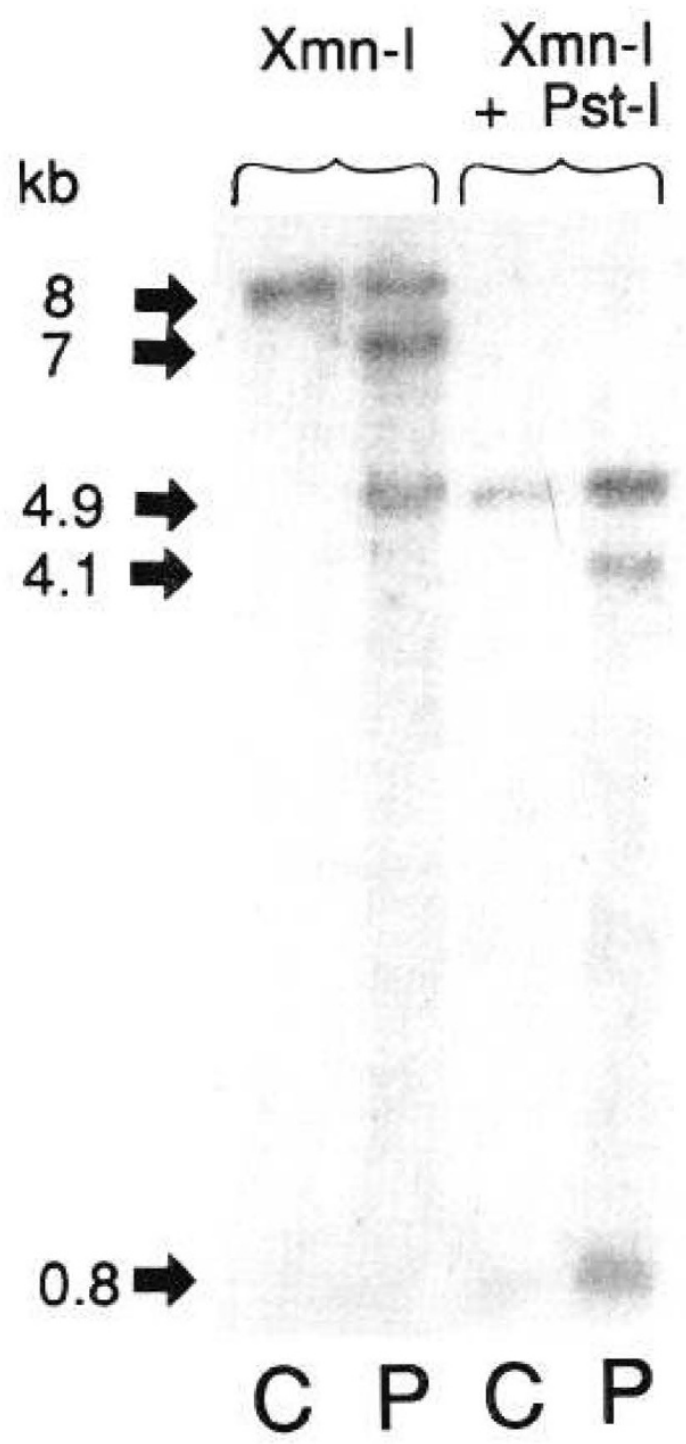

Figure 3. Distribution of DNA fragments in restriction enzyme digests from patient $2(P)$ and a normal control $(C)$ using a $\gamma$-globin gene $(\gamma$ IVS-II) probe.

eration was substantially accelerated, Hb switching nevertheless was not observed to be delayed $(21,22)$, and indeed such infants were shown to have somewhat lower than normal levels of $\mathrm{Hb} \mathrm{F}$. On the other hand, infants who suffered hypoxia in utero as a result of placental insufficiency were observed to have at least moderately increased levels of $\mathrm{Hb} F$, compatible with delayed $\mathrm{Hb}$ switching $(23,24)$. In infants with postnatal hypoxia due to cyanotic congenital heart disease, however, no evidence was found to suggest any change in the Hb switching program (25).

The apparently inconsistent and generally limited influence of these environmental factors in human infants provided support for an alternative hypothesis, viz. that $\mathrm{Hb}$ switching might be governed by a "developmental clock" (26) having basically autonomous activity that functions to coordinate $\mathrm{Hb}$ switching within the overall developmental program. This hypothesis is consistent with the obscrvation that, at birth, $\mathrm{Hb}$ F synthesis by erythroid cells from infants of varying gestational ages correlated closely with the gestational ages of the infants (27). Within this framework, the putative developmen- 
tal clock for sequential $\mathrm{Hb}$ expression could be an intrinsic feature of the erythroid cell lineagc, or alternatively, external factors produced at specific stages of development could act on the erythroid cells to mediate these changes.

Transplantation experiments, in which hematopoietic progenitor cells of fetal or neonatal origin were engrafted into postneonatal recipients, have represented one avenue to approaching this question (28-32). These experiments, however, have yielded unclear and sometimes conflicting results. Moreover, durable transplants were not achieved in any of these studies; none of the transplant recipients survived more than a few weeks. Zanjani et al. (28) performed transplantation studies in sheep, which normally undergo a neonatal $\mathrm{Hb}$ switch similar to that of the human switching process. When hematopoietic progenitor cells from the livers and bone marrow of sheep fetuses were transplanted into an adult recipient, the engrafted cells produced $\mathrm{Hb}$ almost exclusively of the adult type. These observations suggested that factors in the adult hematopoietic environment might have played a significant role in mediating the switch to adult Hb synthesis.

Bunch et al. (29) described experiments in which bone marrow cells from fetal sheep were successfully transplanted into lambs. In these studies, the $\mathrm{Hb}$ that was produced postengraftment was found to be primarily fetal. A gradual increase in the synthesis of adult-type $\mathrm{Hb}$ of donor origin was then observed; however, this transition occurred earlier than was expected from the gestational age of the transplanted cells, but not as rapidly as would have been anticipated if environmental factors were entirely responsible for producing the $\mathrm{Hb}$ switch. A later, more extensive study from the same laboratory (30) resulted in similar observations, leading to the conclusion that "the timing of the switch from fetal to adult hemoglobin in ruminants at least in part reflects inherent programming of the hematopoietic stem cells."

Human transplantation experiments have been reported by Delfini et al. (31) and by Papayannopoulou et al. (32). These studies both involved young children with acute leukemia who received transplants of cells obtained from fetal livers. Although these patients survived for only 27-30 d after the transplants, studies of their bonc marrow demonstrated that engraftment had taken place. Globin synthesis studies with bone marrow cells and blood reticulocytes from these patients, done between 14 and $28 \mathrm{~d}$ posttransplantation, demonstrated $\gamma / \beta$ synthesis ratios ranging from approximately 7 to approximately 20 . The persistence of fetal patterns of expression in these transplanted cells militated against any significant role of environmental factors in effecting the $\gamma$ to $\beta$ switch, suggesting further that the process of $\mathrm{Hb}$ switching is likely to be controlled primarily by a mechanism intrinsic to the erythropoietic progenitor cells.

The findings from the two patients we studied, who achieved long-term marrow engraftment, are also compatible with the notion that hematopoietic progenitor cells from the fetus and newborn are intrinsically programmed for $\gamma$-globin gene expression. In both of these patients, one whose marrow graft contained an apparent $\gamma$-globin genc triplication and the other who presumably had a normal complement of globin genes, the $\gamma$ to $\beta$ switching process seemed to follow the temporal sequence that would have been expected to occur during the first months of infancy.

In the interpretation of these observations, alternative explanations for the transient elevation of $\mathrm{Hb} \mathrm{F}$ levels in these patients also need to be considered. The Fanconi anemia syndrome, the disorder for which both of these patients received hematopoietic cell transplants, is typically associated with increased levels of $\mathrm{Hb} \mathrm{F}$ (33), and indeed, before their transplants both of these children had elevated levels of $\mathrm{Hb} \mathrm{F}$. Since the time of their engraftment, however, both of these patients have continued to have normal hematologic phenotypes, and there has been no indication of repopulation of their bone marrow by their original cell lines. Neither of the donors of the transplanted cord blood cells had any demonstrable feature of the Fanconi anemia syndrome, although both of them have a high probability of being hetcrozygous carriers of this abnormality. The parents of these children also had normal hematologic findings. Carriers of the Fanconi anemia syndrome gene typically do not produce elevated levels of $\mathrm{Hb} \mathrm{F}$, but it is possible that under conditions of stress reticulocytosis their hematopoiesis might be accompanied by the production of higher than normal levels of $\mathrm{Hb} \mathrm{F}$. In any case, inasmuch as $\mathrm{Hb} \mathrm{F}$ is synthesized in relatively low amounts even in homozygous Fanconi anemia patients, a process of this kind would not likely be sufficient to account for the levels of $\mathrm{Hb} \mathrm{F}$ we observed in these patients.

Stress reticulocytosis has been shown to be accompanied by a transient increase in $\mathrm{Hb} \mathrm{F}$ synthesis in patients in marrow regeneration after treatment for iron deficiency (34), in the recovery phase of transient erythroblastopenia of childhood (35), and after phlcbotomy (35) or bone marrow transplantation (36). In some patients after engraftment of transplanted bone marrow, their increased rate of synthcsis of $\mathrm{Hb} \mathrm{F}$ was also accompanied by ${ }^{\mathrm{G}} \gamma /{ }^{\mathrm{A}} \gamma$ ratios that corresponded to the fctal/ newborn pattern (36). Nevertheless, the maximum rates of synthesis of $\mathrm{Hb} \mathrm{F}$ in the patients recovering from allogeneic bone marrow transplants, who served as "controls" in our study, were substantially less than what we observed after the transplantation of cord blood cells and could not nearly account for the full extent of these changes.

Recent efforts to define the regulatory mechanisms that are responsible for globin switching have used cell hybrids that include part or all of human chromosome 11, which includes the $\beta$-globin locus $(37,38)$, and transgenic mice that express human globins $(39,40)$. Models that have been devcloped from studies with these experimental systems have suggested that the regulation of $\mathrm{Hb}$ switching may involve processes of both stage-specific autonomous gene silencing $(39,41)$ and competitive interactions between globin-gene promoter and enhancer elements $(38,42)$. Evidence from transgenic animal studies also suggests that trans-acting "environmental" factors play some role in this process (39).

Acknowledgments. The authors thank Dr. Joseph DeSimone for the $\gamma$ IVS-II probe. Dr. Leonard Valentino kindly supplied the postengraftment blood samples from allogeneic bone marrow transplant patients. Julia Ferrari performed the hematologic studics. 


\section{REFERENCES}

1. Broxmeyer HE, Douglas GW, Hangoc G, Cooper S, Bard J, English D, Arny M, Thomas L, Boyse EA 1989 Human umbilical cord blood as a potential source of transplantable hematopoietic stem/progenitor cells. Proc Natl Acad Sci USA 86:3828-3832

2. Rubinstein P, Rosenfield RE, Adamson JW, Stevens CE 1993 Stored placental blood for unrelated bone marrow reconstitution. Blood 81:1679-1690

3. Broxmeyer HE, Kurtzberg J, Gluckman E, Auerbach AD, Douglas G, Cooper S, Falkenburg JHF, Bard J, Boyse EA 1991 Umbilical cord blood hematopoietic stem and repopulating cells in human clinical transplantation. Blood Cells 17:313-329

4. Honig GR, Telfer MC, Rosenblum BB, Vida LN $1989 \mathrm{Hb}$ Warsaw $(\beta 42 \mathrm{Phe} \rightarrow$ Val): an unstable hemoglobin with decreased oxygen affinity. I. Hematologic and clinical expression. Am J Hematol 32:36-41

5. Honig GR, Shamsuddin M, Vida LN, Mompoint M, Valcourt E, Bowie LJ, Jones EC, Powers PA, Spritz RA, Guis M, Embury SH, Conboy J, Kan YW, Mentzer WC, Wei SC, Hirata RK, Waloch J, O'Riordan JF, Goldstick TK 1984 Hemoglobin Evanston $(\alpha 14 \operatorname{Trp} \rightarrow \mathrm{Arg})$ : an $\alpha$-chain variant cxpressed as $\alpha$ thalassemia. J Clin Invest 73:1740-1749

6. Strahler JR, Rosenblum BB, Hanash SM 1983 A silent, neutral substitution detected by reverse-phase high-performance liquid chromatography: hemoglobin Beirut. Science 221:860-862

7. Honig GR, Mason RG, Vida LN, Shamsuddin M 1974 Synthesis of hemoglobin Abraham Lincoln ( 332 Leu $\rightarrow$ Pro). Blood 43:657-664

8. Honig GR, Rowan BQ, Mason RG 1969 Unequal synthesis of complementary globin chains of human fetal hemoglobin by the effect of L-O-methylthreonine. J Biol Chem $244: 2027-2032$

9. Clegg JB, Naughton MA, Weatherall DJ 1966 Abnormal human hemoglobins. Separation and characterization of the $\alpha$ and $\beta$ chains by chromatography and the determination of two new variants, $\mathrm{Hb}$ Chesapeake and $\mathrm{Hb} \mathrm{J}$ (Bangkok). J Mol Bio 19:91-108

10. Poncz M, Solowiejczyk D, Harpel B, Mory Y, Schwartz E, Surrey S 1982 Construction of human gene libraries from small amounts of peripheral blood: analysis of $\beta$-like globin genes. Hemoglobin 6:27-36

11. Sambrook J, Fritsch EF, Maniatis T 1989 Molecular Cloning: A Laboratory Manual, 2nd Ed. Cold Spring Harbor Laboratory, Cold Spring Harbor, NY, 9.24-9.57

12. Gluckman E, Broxmeyer HE, Aucrbach AD, Fricdman HS, Douglas GW, Devergie A, Esperou H, Thierry D, Socie G, Lehn P, Cooper S, English D, Kurtzberg J, Bard J, Boyse EA 1989 Hematopoietic reconstitution in a patient with Fanconi's anemia by means of umbilical-cord blood from an HLA-identical sibling. N Engl J Med $321: 1174-1178$

13. Kohli-Kumar M, Shahidi NT, Broxmeyer HE, Masterson M, Delaat C, Sambrano J, Morris C, Auerbach A, Harris RE 1993 Haemopoietic stem/progenitor cell transplant in Fanconi anaemia using HLA-matched sibling umbilical cord blood cells. Br J Haematol 85:419-422

14. Kleihauer EF, Braun H, Betke K 1957 Demonstration von fetalem Hämoglobin in den Erythrocyten cines Blutausstrichs. Klin Wschr 35:637-638

15. Efremov GD, Filipce V, Gjorgovski I, Juricic D, Stojanovski N, Harano $\Upsilon$, Nakatsuji T, Kutlar A, Kutlar F, Bakioglu I, Huisman THJ $1986^{\mathrm{G}} \gamma^{\mathrm{A}} \gamma(\delta \beta)^{\circ}$-thalassaemia and a new form of $\gamma$ globin gene triplication identified in the Yugoslavian population. Br J Hacmatol 63:17-28

16. Ingram VM 1963 The Hemoglobins in Genetics and Evolution. Columbia University Press, New York, pp 120-122

17. Stamatoyannopoulos G, Veith R, Galanello R, Papayannoupoulou $T 1985$ Hb F production in stressed erythropoicsis: observations and kinetic models. Ann NY Acad Sci 445:188-197

18. Papayannoupoulou T, Kalmantis TH, Stamatoyannopoulos G 1979 Cellular regulation of hemoglobin switching: evidence for inverse relationship between fetal hemoglobin synthesis and degree of maturity of human erythroid cells. Proc Natl Acad Sci USA $76: 6420-6424$

19. DeSimone J, Biel SI, Heller P 1978 Stimulation of fetal hemoglobin synthesis in baboons by hemolysis and hypoxia. Proc Natl Acad Sci USA 75:2937-2940
20. DeSimone J, Biel M, Heller P 1982 Maintenance of fetal hemoglobin (Hb F) elevations in the baboon by prolonged erythropoietic stress. Blood 60:519-523

21. Brody S, Engström L 1960 Foetal and adult haemoglobin in newborn infants with erythroblastosis foetalis. Acta Pacdiatr 49:868-878

22. Oppé TE, Fraser ID 1961 Foetal haemoglobin in haemolytic disease of the newborn. Arch Dis Child 36:507-510

23. Bromberg YM, Abrahamov A, Salzberger M 1956 The effect of maternal anoxaemia on the foetal haemoglobin of the newborn. J Obstct Gynaecol 63:875-877

24. Bard H 1974 The effect of placental insufficiency on fetal and adult hemoglobin synthesis. Am J Obstet Gynecol 120:67-72

25. Bard H 1976 Postnatal synthesis of adult and fetal hemoglobin in infants with congenital cyanotic heart disease. Biol Neonatc 28:219-224

26. Stamatoyannopoulos G, Papayannoupoulou T, Brice M, Kurachi S, Nakamoto B, Lim G, Farquhar M 1981 Cell biology of hemoglobin switching I. The switch from fetal to adult hemoglobin formation during ontogeny. In: Stamatoyannopoulos G, Nienhuis AW (eds) Hemoglobins in Development and Diffcrentiation. Alan R Liss, New York, pp 287-305

27. Bard H, Makowski EL, Meschia G, Battaglia FC 1970 The relative rates of synthesis of hemoglobins $\mathrm{A}$ and $\mathrm{F}$ in immature red cells of newborn infants. Pediatrics 45:766-772

28. Zanjani ED, McGlave PB, Bhakthavathsalan A, Stamatoyannopoulos G 1979 Sheep fetal hacmatopoictic cells produce adult haemoglobin when transplanted in the adult animal. Nature 280:495-496

29. Bunch C, Wood WG, Weatherall DJ, Robinson JS, Corp MJ 1981 Haemoglobin synthesis by fetal erythroid cells in an adult environment. Br J Haematol 49:325-336

30. Wood WG, Bunch C, Kelly S, Gunn Y, Breckon G 1985 Control of haemoglobin switching by a developmental clock? Nature 313:320-323

31. Delfini C, Saglio G, Mazza U, Muretto P, Filippetti A, Lucarelli G 1983 Fetal haemoglobin synthesis following fetal liver transplantation in man. $\mathrm{Br} J$ Hacmatol 55:609-614

32. Papayannopoulou T, Nakamoto B, Agostinelli F, Manna M, Lucarclli G, Stamatoyannopoulos G 1986 Fetal to adult hemopoietic cell transplantation in humans: insights into hemoglobin switching. Blood 67:99-104

33. Shahidi NT, Gerald PS, Diamond LK 1962 Alkali-resistant hemoglobin in aplastic anemia of both acquired and congenital types. N Engl J Med 266:117-120

34. Dover GJ, Boyer SH, Zinkham WH 1979 Production of erythrocytes that contain fetal hemoglobin in anemia. Transient in vivo changes. J Clin Invest 63:173-176

35. Papayannopoulou T, Vichinsky E, Stamatoyannopoulos G 1980 Fetal Hb production during acute erythroid expansion. I. Observations in patients with transicnt erythroblastopenia and post-phlebotomy. Br J Hacmatol 44:535-546

36. Alter BP, Rappeport JM, Huisman THJ, Schroeder WA, Nathan DG 1976 Fetal erythropoiesis following bone marrow transplantation. Blood 48:843-853

37. Enver T, Bricc M, Karlinsey J, Stamatoyannopoulos G, Papayannopoulou T 1991 Developmental regulation of fetal to adult globin gene switching in human fetal erythroid $\times$ mouse erythroleukemia cell hybrids. Dev Biol 148:129-137

38. Kim CG, Epner EM, Forrester WC, Groudine M 1992 Inactivation of the human $\beta$-globin gene by targeted insertion into the $\beta$-globin locus control region. Genes Dev 6:928-938

39. Raich N, Enver T, Nakamoto B, Josephson B, Papayannopoulou T, Stamatoyannopoulos G 1990 Autonomous developmental control of human embryonic globin gene switching in transgenic micc. Science 250:1147-1149

40. Peterson KR, Clegg CH, Huxley C, Josephson BM, Haugen HS, Furukawa T, Stamatoyannopoulos G 1993 Transgenic mice containing a 248-kb yeast artificial chromosome carrying the human $\beta$-globin locus display proper developmental control of human globin genes. Proc Natl Acad Sci USA 90:7593-7597

41. Dillon N, Grosveld F 1991 Human $\gamma$-globin genes silenced independently of other genes in the $\beta$-globin locus. Nature 350:252-254

42. Enver T, Raich N, Ebens AJ, Papayannopoulou T, Costantini F, Stamatoyannopoulos G 1990 Developmental regulation of human fetal-to-adult globin gene switching in transgenic mice. Naturc 344:309-313 